\title{
Electrical properties of sugar palm nanocrystalline cellulose reinforced sugar palm starch nanocomposites
}

\author{
M.D. Hazrol1), S.M. Sapuan ${ }^{1), 2), *), ~ R . A . ~ I l y a s ~}{ }^{1), 2)}$, M.L. Othman ${ }^{3)}$, S.F.K. Sherwani ${ }^{1)}$ \\ DOI: dx.doi.org/10.14314/polimery.2020.5.4
}

\begin{abstract}
In this study, the effect of sugar palm nanocrystalline cellulose (SPNCC) loading $(0.00-0.10 \mathrm{wt} \%)$ on the electrical resistance, resistivity, and conductivity of SPS/SPNCC (SPS - sugar palm starch) nanocomposite films were evaluated. The experiments were conducted using the four-probe method and Ohm's law, resistivity and conductivity equations were utilized to obtain the electrical properties. The results revealed that the resistivity values of SPS/SPNCC films were found to be in the range of $3.1 \cdot 10^{2}$ to $1.5 \cdot 10^{4}(\Omega \cdot \mathrm{cm})$.
\end{abstract}

Keywords: sugar palm nanocellulose, sugar palm starch, biopolymer, resistivity, conductivity.

\section{Właściwości elektryczne nanokompozytów skrobi z palmy cukrowej wzmocnionej włóknami nanokrystalicznej celulozy z palmy cukrowej}

\begin{abstract}
Streszczenie: Oceniono wpływ dodatku nanokrystalicznej celulozy otrzymanej z palmy cukrowej (SPNCC) (0,00-0,10\% mas.) na rezystancję elektryczną, rezystywność i przewodnictwo folii wytworzonych z nanokompozytów (SPS/SPNCC) na bazie skrobi z palmy cukrowej (SPS). Badania przeprowadzono metodą czterosondową z zastosowaniem prawa Ohma; właściwości elektryczne określono na podstawie równań rezystywności i przewodności. Stwierdzono, że wartość rezystywności folii SPS/SPNCC mieści się w zakresie konduktywności od $3,1 \cdot 10^{2}$ do $1,5 \cdot 10^{4}(\Omega \cdot \mathrm{cm})$.
\end{abstract}

Słowa kluczowe: nanoceluloza z palmy cukrowej, skrobia z palmy cukrowej, biopolimer, rezystywność, przewodnictwo.

Electrical resistivity is a fundamental property that quantifies how strongly a design material opposes the flow of electric current. The surface resistivity decreases with the increase in fiber content in composite materials, while volume resistivity increases [1]. By determining the conductivity and resistivity, new forms of biocomposites are introduced as new materials that can either conduct electricity or oppose the flow of electrical current. Some materials resist the flow of current more than others, and this is known as the electrical resistivity of the substance [2]. Lattice vibrations and phonon scattering play a role in disrupting the mean free path of electrons. Most engineering plastics and bioplastic materials are known as electrical insulators. In insulators, a tiny amount of

\footnotetext{
1) Universiti Putra Malaysia, Department of Mechanical and Manufacturing Engineering, Advanced Engineering Materials and Composites Research Centre (AEMC), 43400 UPM Serdang, Selangor, Malaysia.

2) Institute of Tropical Foresty and Forest Products, 43400 UPM Serdang, Selangor, Malaysia.

3) Universiti Putra Malaysia, Department of Electrical and Electronic Engineering, 43400 UPM Serdang, Selangor, Malysia.

*) Author for correspondence: sapuan@upm.edu.my
}

free passage are available to inhibit the ability of electric current flow and effect the dissipation of energy from the materials and resist a potential difference between the end points to another of a given specimen of plastic. According to Naik et al. [1], resistivity measurements are often used to check the uniformity in synthesis and processing. Humidity affects the volume resistance of different insulators to different extents. However, for some applications, a moderate electrical conductivity is required in which materials with medium electrical conductivity can be used for electrical static discharge purposes, whereas those of high conductivity materials can be utilized as electronic equipment housings for which electromagnetic interference shielding properties are required [1, 3]. Naik et al. [1], used the composites of banana, hemp, and agave with HDPE (high density polyethylene) resin. The composites were separately prepared in different ratios, $60: 40,55: 45,50: 50$, and $45: 55(\mathrm{wt} / \mathrm{wt})$. They concluded that the surface resistivity decreased with higher fiber contents of the composites, while volume resistivity increased. Xie et al. [4] used acrylated palm oil (APO) for the formation of an internally cross-linked nanostructure that could sustainably be used as drug carriers through the radiation-induced initiator method. Besides that, the electrically conduct- 
ing polymer composites have numerous advantages over their pure metal counterparts, such as mechanical shock absorption, corrosion resistance, lower cost, conductivity control, ease of manufacture, reduced weight and high flexibility [5-9].

Currently in Malaysia, sugar palm fibers and sugar palm stem are waste materials of the processed sugar palm sap and fruits for food products [10-15]. After these main products are extracted from the tree, the undesired components of the plant, such as sugar palm fibers and stem, are burnt and dumped, where they would decompose naturally (Fig. 1) [16-20]. The findings from a few studies have showed that sugar palm fibers have a huge potential as a reinforcing component in various highperformance polymer composite applications, as they are rich in cellulose [21-26], hence, increasing its commercial value as waste materials from sugar palm cultivation [27-33]. Thus, this study continues experimenting with the electrical properties of sugar palm nanocrystalline cellulose reinforced with sugar palm starch biopolymer.

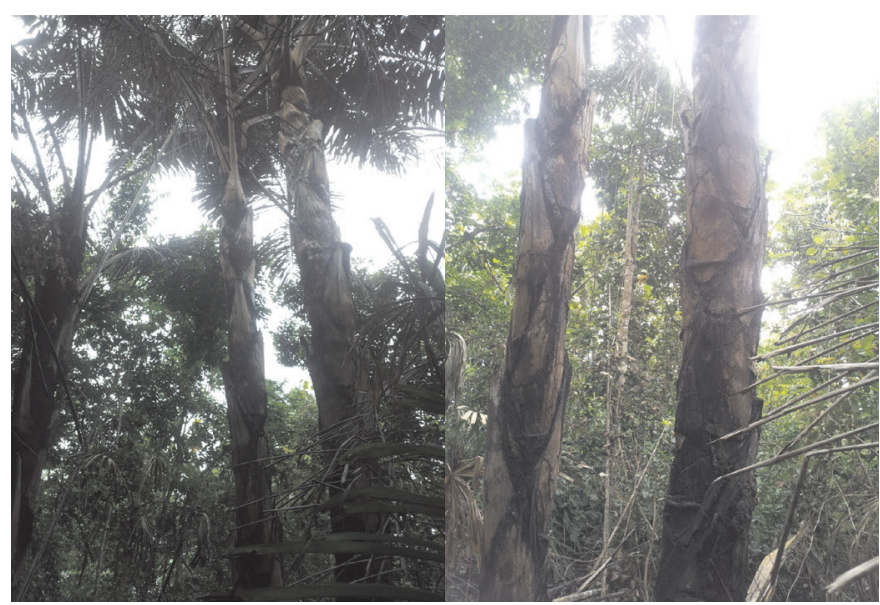

Fig. 1. Sugar palm fibers and stems, were burnt and dumped after the main products were extracted from the trees

It is well known that the electrical conductivity of conducting polymers depends on a number of factors, such as the number of defect sites, extent of conjugation, the presence of conjugated crosslinks between chains, the degree of closeness of approach of different chains and their orientations relative to each other [34]. The conductivity and insulation in solid substances are important in determining the electrical carrying current or charge in a material [35], thus making copper, silver and aluminum the best materials for wiring buildings and appliances. The objective of this paper is to determine the effect of different sugar palm nanocrystalline cellulose (SPNCC) loadings (0.00-0.10 wt \%) on the resistance, resistivity, and conductivity of SPS/SPNCC (SPS - sugar palm starch) nanocomposite films. The films are then resized to $1 \mathrm{~mm}$ (length) $\times 1 \mathrm{~mm}$ (width) $\times(0.120-0.130 \mathrm{~mm})$ (thickness) sized dimensions to fit into the electrical testing probe instrument.

\section{EXPERIMENTAL PART}

\section{Materials}

The fiber and starch used was from sugar palm (Arenga pinnata) fiber or ijuk fiber. This fiber is black/brown in colour, with a varied diameter up to $0.50 \mathrm{~mm}$. The fiber becomes hardened when in contact with water. Sugar palm fibers have some advantages over traditional reinforcement fiber materials in terms of cost, density, being renewable, non-toxic, abrasiveness and biodegradability. Sugar palm fibers (SPF) and sugar palm starch (SPS) (Table 1) were obtained from sugar palm trees at Jempol, Negeri Sembilan (Malaysia). Plasticizers, such as sodium hydroxide, sodium chlorite, acetic acid, sorbitol (Table 2) and glycerol (Table 3) were provided by Sue Evergreen Sdn. Bhd. (Semenyih, Malaysia).

T a b l e 1. Sugar palm starch specification

\begin{tabular}{l|c}
\hline Properties & Specification \\
\hline Density & $1.54 \mathrm{~g} / \mathrm{cm}^{3}$ \\
Ash content & $0.20 \%$ \\
Amylose content & $37.60 \%$ \\
Protein content & $0.10 \%$ \\
Fat content & $0.27 \%$ \\
Water content & $15 \%$ \\
\hline
\end{tabular}

T a b l e 2. Sorbitol specification

\begin{tabular}{l|c}
\hline Properties & Specification \\
\hline Assay (HPLC) & $>99.0 \%$ \\
Heavy metals (as Pb) content & $<0.001 \%$ \\
Mannitol (HPLC) content & $<0.2 \%$ \\
Water content & $<0.2 \%$ \\
\hline
\end{tabular}

T a b l e 3. Glycerol specification

\begin{tabular}{l|c}
\hline Properties & Specification \\
\hline Assay & $99.8 \%$ \\
Density 20/4 & $1.257-1.262 \mathrm{~g} / \mathrm{cm}^{3}$ \\
Refractive index & $1.471-1.473$ \\
$\mathrm{pH}$ & $6.0-7.0$ \\
Sulphate ash content & Max. 0.005\% \\
Chloride $\left(\mathrm{Cl}^{\circ}\right.$ content & Max 0.0001\% \\
Sulphate $\left(\mathrm{SO}_{4}^{+}\right)$content & Max 0.0005\% \\
Ammonium $\left(\mathrm{NH}_{4}^{+}\right)$content & Max 0.0005\% \\
Arsenic $(\mathrm{As})$ content & Max 0.0004\% \\
Copper $(\mathrm{Cu})$ content & Max 0.0005\% \\
Iron $(\mathrm{Fe})$ content & Max 0.0005\% \\
Lead $(\mathrm{Pb})$ content & Max 0.0005\% \\
Sugar $(\mathrm{glucose})$ content & Max 0.0004\% \\
\hline
\end{tabular}



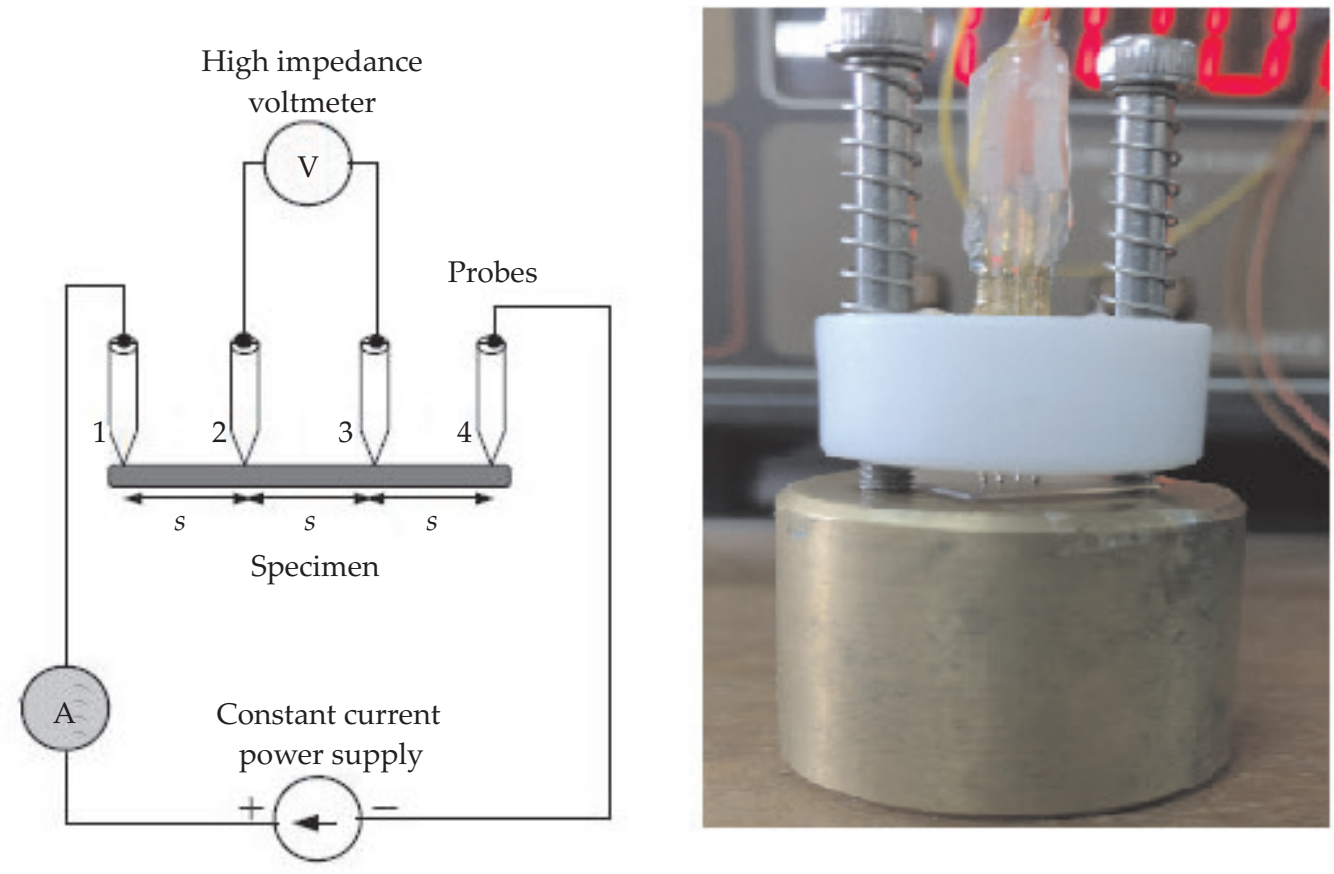

Fig. 2. The arrangement of four probes that measure voltage $(V)$ and supply current $(I)$ to the surface of the thin film

\section{Preparation of SPNCCs}

The sugar palm starch (SPS) was obtained from the stem of a mature sugar palm tree. Initially, the tree was cut down using a chainsaw and the mixture of woody fiber and starch powder from the interior part of the stem was collected. In order to gain a uniform SPF size $(2 \mathrm{~mm})$, the grinding and screening process was done using a Fritsch Jaw Crusher Pulverisette mill 1. The procedure for the cellulose preparation was adapted from a previous report [36]. The extraction of sugar palm cellulose (SPC) from SPF was carried out using two main processes; delignification and mercerization. Both were performed in accordance with ASTM D1104-56 (1978) and ASTM D1103-60 (1977) for the removal of lignin and hemicellulose, respectively. SPNCCs were prepared by acid hydrolysis of the obtained cellulose $[19,37]$. The operating conditions employed for the successful continuity of this process included aqueous $\mathrm{H}_{2} \mathrm{SO}_{4}(60 \mathrm{wt} \%)$, mechanical stirring with a rotation speed of $1200 \mathrm{rpm}$ at $45^{\circ} \mathrm{C}$ temperature for a period of $45 \mathrm{~min}$. The ratio of the obtained cellulose to $\mathrm{H}_{2} \mathrm{SO}_{4}$ solution was $5: 100$ (wt \%). The hydrolyzed cellulose samples were washed 4 times by centrifugation $(6000 \mathrm{rpm}, 20 \mathrm{~min}$, and $10^{\circ} \mathrm{C}$ ) to eliminate the leftover sulphuric acid. The suspension was then dialyzed against distilled water until a constant $\mathrm{pH}$ was reached (6.5 to 7$)$. Then, the resultant suspension was sonicated for $30 \mathrm{~min}$.

\section{Preparation of the SPS/SPNCC nanocomposite films}

The solution casting method was used in fabricating the plastified SPS/SPNCC composite films. A blend of sorbitol, glycerol, starch, SPNCCs and distilled water was formed and sonicated to acquire a homogenous nanocomposite film. Briefly, a solution of SPNCC was prepared by mixing and sonicating it with $180 \mathrm{~cm}^{3}$ of distilled water with a known concentration of SPNCC $(0.00,0.02,0.04,0.06,0.08$ and $0.10 \mathrm{wt} \%$ on starch basis) for 30 minutes. Then, $10 \mathrm{~g}$ of SPS and plasticizer ( $30 \mathrm{wt} \%$ on starch basis) were mixed with the SPNCC solutions and stirred at $1000 \mathrm{rpm}$ for 20 minutes at $80^{\circ} \mathrm{C}$ in a disperser for the starch to be gelatinized. This procedure was to ensure that the starch granules were uniformly dissolved and a homogenous dispersion was simultaneously formed $[38,39]$. The ratio of plasticizer used was $1: 1$ of sorbitol and glycerol. Then, the film-forming suspension was left to cool and placed under a vacuum to remove air bubbles inside the suspension before $45 \mathrm{~g}$ of the suspension was cast into each petri dish with a $15 \mathrm{~cm}$ diameter. The petri dishes containing the film-forming solution were placed in an oven at $40^{\circ} \mathrm{C}$ overnight.

\section{Methods of testing}

The film was prepared for the required dimension size of the four-probe test apparatus (Fig. 2). In determining the resistivity and conductivity (Fig. 3) for natural fiber

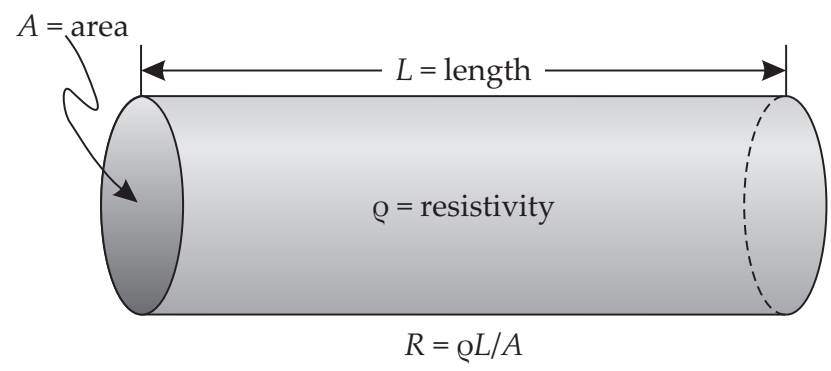

Fig. 3. Electrical conductor 
composite materials, the four-probe test method was used. The theory of using the four-probe test at constant temperature induced the resistance $R$ value. Conductivity is the reciprocal of the resistivity value across length $L$ from one end point to the other of a material. The distance from one probe to another $(S)$ is fixed at $1 \mathrm{~mm}$.

$$
\text { Ohm's Law } V=I R
$$

where: $V$ - voltage, $I$ - current.

$$
\begin{aligned}
\text { Resistivity } \mathrm{Q} & =2 \pi S R[\Omega \cdot \mathrm{m}] \\
\text { Conductivity } \sigma & =1 / \mathrm{Q}[\mathrm{Siemens} / \mathrm{m}]
\end{aligned}
$$

From the equation above, resistivity is gained from the resistance value measured from the four-probe instrument. The current was recorded using a Keithley 236 Source Measure Unit while the voltage measurements were recorded using Picotest M3500A Digital Multimeter. From the experiments, the current value was constant at $0.00,0.02,0.04,0.06,0.08,0.10,0.15$, and $0.20 \mu \mathrm{A}$ and voltage value was determined for each constant current value. The resistance can be calculated by using Ohm's Law, Equation (1). Unit $\varrho$ is the resistivity of the conductor and its units are Ohm meter. A semiconductor has electrical conductivity intermediate in magnitude between that of a conductor and insulator. From the equation (3), the conductivity $\sigma$ is inversely proportional to the resistivity of a material and carries the unit Siemens $/ \mathrm{m}$.

\section{RESULTS AND DISCUSSION}

\section{Measurement of resistance}

The resistance $R$ was measured using Ohm's law by the computed voltage and experimental current input. The readings were taken ten times for each concentration sample with various current supply values using the four-probe method. The four-probe apparatus is one of

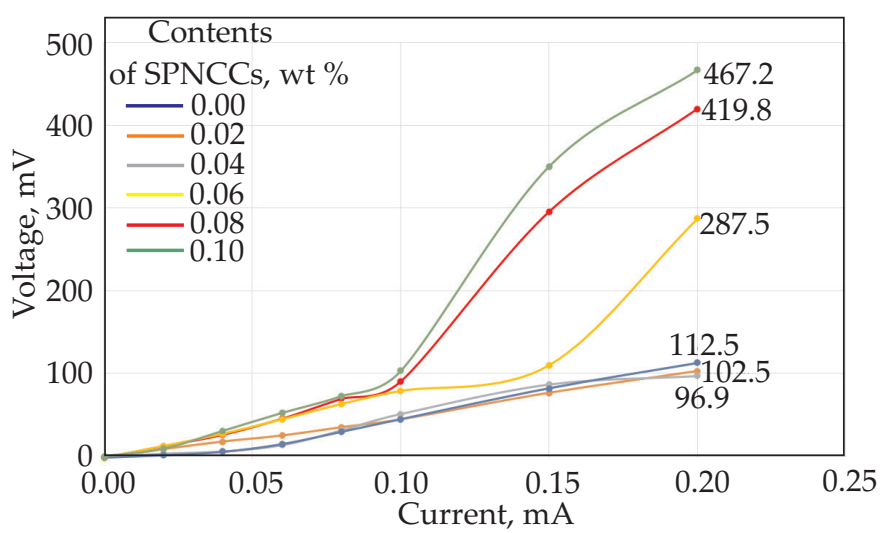

Fig. 4. Voltage $(\mathrm{mV})$ and current $(\mu \mathrm{A})$ measurement of SPS/SPNCC films the standard and most heavy used apparatus for the measurement of resistivity of semiconductors. Figure 4 shows the experimental readings of SPS/SPNCC films resistance with concentration of SPNCCs 0.00, 0.02, 0.04, 0.06, 0.08 and $0.10 \mathrm{wt} \%$.

Based on Fig. 4, the resistance values are derived from the current and voltage readings across the SPS/SPNCC films. Each resistance result was measured with an increase in the current value. In this particular analysis, conducted for a film with concentration of $0.10 \mathrm{wt} \%$, we see the greatest potential difference value across the circuit, and this shows that the voltage from one contact to another inside the circuit through the film is the largest among the five formulations. The lowest resistance is for the SPS/SPNCC film with a concentration of $0.04 \mathrm{wt} \%$ SPNCC, having a resistance value of $484.34 \cdot 10^{3} \Omega$. Thus, the effect on the conductivity value of the material allows the electricity to flow is low from one end point to another.

\section{Resistivity of SPS/SPNCCs films at different SPNCC concentration}

Accurate electrical and analytical measurements allowed us to determine the dependence of resistivity with different concentrations of SPNCC values at room temperature. The value of resistivity was obtained from the resistivity formula from the four probe measurement. The value of resistivity was calculated based on the resistance gained from the graph data presented in Fig. 4. This concluded that the relationship of resistivity and resistance are directly proportional and correlated with each other, which carries the same characteristics in materials at room temperature.

Figure 5 shows the measurement of resistivity with different amounts of current being applied.

The resistivity was determined with different amounts of current ranging from $(0.00$ to $0.20 \mu \mathrm{A})$ supplied by the digital multimeter. From the graph shown in Fig. 5, the resistivity values increased with the higher fiber loading of the SPNCCs. The differences between the concentra-

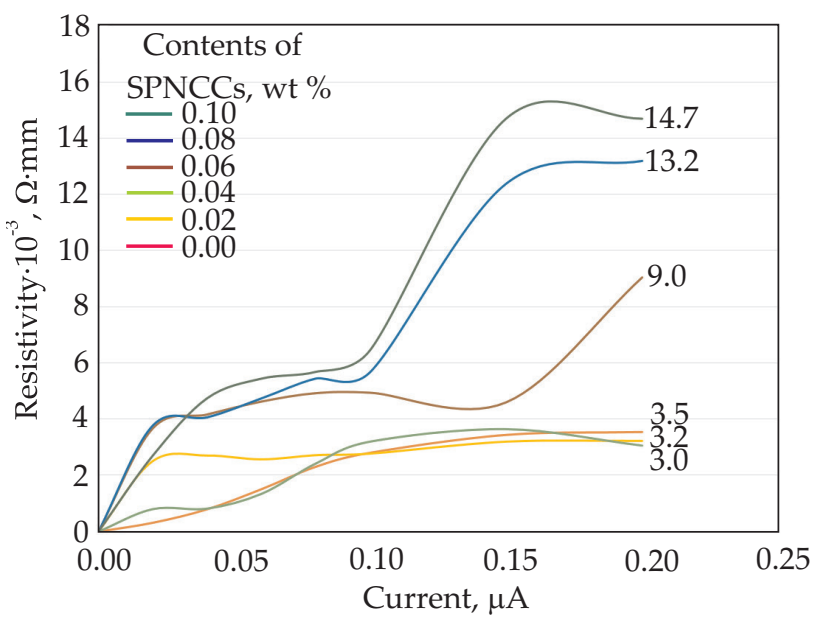

Fig. 5. Resistivity curve of SPS/SPNCC films 
tion of SPNCCs by the analytical technique and electrical resistivity readings are reported in Fig. 5. It is shown that with $0.1 \mathrm{wt} \%$ concentration of SPNCC resulted in the greatest resistivity value, which was $14.68 \cdot 10^{3}(\Omega \cdot \mathrm{mm})$. This is due to the high volume resistivity of starch. These results are in agreement with the Naik et al. [1] findings that showed that resistivity increases with higher amounts of SPNCCs contents in a matrix of sugar palm, starch biopolymer composite.

\section{Conductivity of SPS/SPNCC film at different SPNCC concentrations}

In daily life, natural and synthetic fiber reinforced polymer composites are used extensively in household appliances. Thus, by measuring the electrical conductivity of a material, it can be vital to prevent current leakage and exceeding the amount of current allowed to flow through the human body. Figure 6 shows the conductivity of SPS/SPNCC films.

The conductivity was determined with different amounts of current ranging from $0.0-0.20 \mu \mathrm{A}$, and the concentration of SPNCC in the film from $0.00-0.10 \mathrm{wt} \%$. Figure 6 depicts that the values of resistivity and conductivity of the material are inversely proportional to each other. From 0.00 to $0.05 \mu \mathrm{A}$ the conductivity of SPS/SPNCC films show a huge spike that reduced and remained stable after $0.1 \mu \mathrm{A}$. It was found that the peak conductivity occurred with films carrying the concentration of $0.00 \mathrm{wt} \%$ and current value at $0.02 \mu \mathrm{A}$, where the fiber holds more charge before it is discharged and becomes stable. It is also discovered that $0.10 \mathrm{wt} \%$ concentration of SPNCC gave the least electrical conductivity value, which is $6.813 \cdot 10^{-5} \mathrm{~S} / \mathrm{mm}$. The trend observed from the $0.10 \mathrm{wt} \%$ concentration trace shows a good result with an increase in current value. The same concept could not be applied to other concentrations since the highest amount of conductivity in SPS/SPNCCs film is at $0.00 \mathrm{wt} \%$, which has

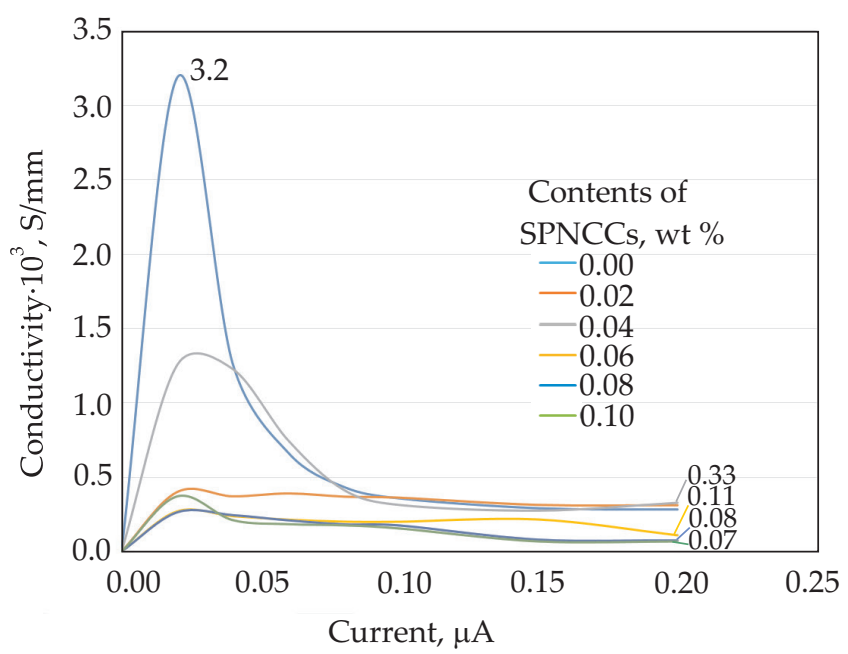

Fig. 6. Conductivity of SPS/SPNCC films with different concentration of SPNCCs a value of $31.84 \cdot 10^{-4} \mathrm{~S} / \mathrm{mm}$. These results corroborate the findings of a great deal of the previous work by Bhardwaj [5] using rice husk reinforced plastic, which has a resistivity of $90.9 \cdot 10^{4} \Omega \cdot \mathrm{cm}$ where they described that the electrical conductivity increased as the natural fiber content in the rice husk/epoxy increased.

\section{Resistance of layered film}

The durability and resistance of a material can be increased by adding an extra layer of materials. Thus, it is important to know how this additional, protective layer can enhance the overall physical behavior and protection to surroundings. This study measured the effect of the number of layers in the film on the changes in resistance of the materials. The readings were taken ten times for single, double and triple layers of SPS/SPNCC films having $0.10 \mathrm{wt} \%$ of SPNCCs concentration with different current supplies from $0.0-0.50 \mu \mathrm{A}$ using the four-probe-method. Figure 7 shows the resistance values of layered SPS/SPNCC films.

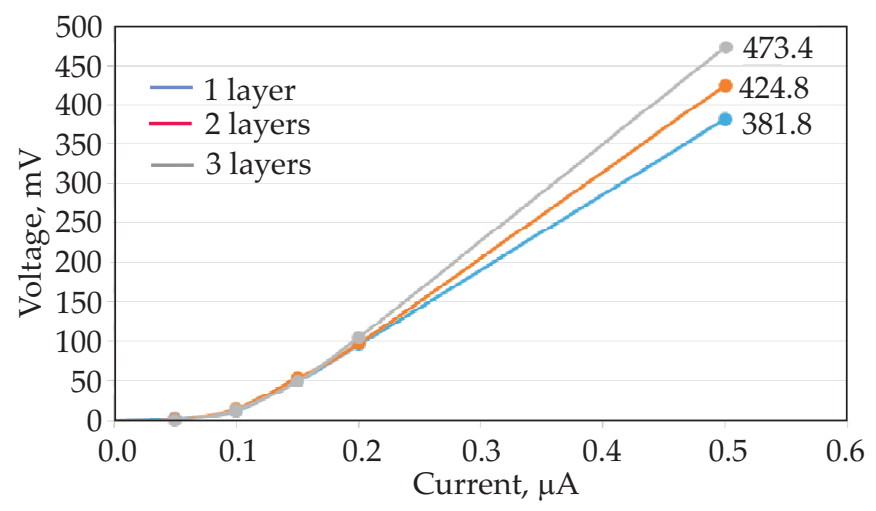

Fig. 7. Resistance of materials with a different number of SPC/SPNCCs film layers

Based on Fig. 7, the resistance values are derived from current and voltage readings across SPS/SPNCC films with $0.10 \mathrm{wt} \%$ of SPNCC concentration. Each resistance result is measured by increasing the current values. In this particular analysis of current value at $0.5 \mu \mathrm{A}$, films with three layers of SPS/SPNCCs shows a resistance of $94.68 \cdot 10^{4} \Omega$, which carries a higher resistance value compared to single and double layered films. This shows that the current and voltage passing through the single layered film is slightly lower compared with film with two and three layer sample. The lowest resistances, as shown above, are from SPS/SPNCC films with single layers that have a resistance value of $76.37 \cdot 10^{4} \Omega$. It is observed that SPS/SPNCC films with higher currents will increase the resistance value of the film thus giving more protection from electrical circuit current leakage.

\section{Measurement of resistivity on layered effect}

The resistivity was determined with a current supply ranging from $0.0-0.50 \mu \mathrm{A}$. The value of resistivity was calculated based on the resistance gained as shown in Fig. 7. 


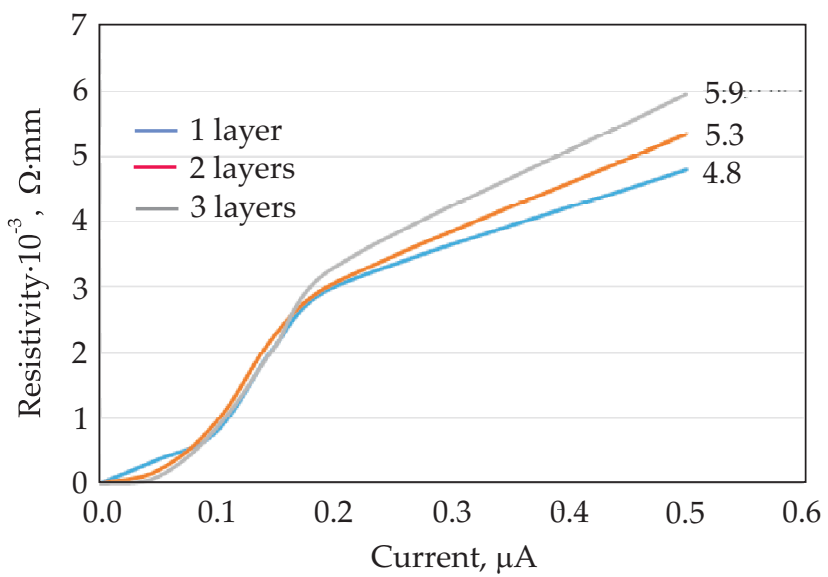

Fig. 8. Resistivity of materials with different number of SPC/SPNCC film layers

This revealed that the relationship of resistance and the number of layers of applied film are directly proportional and correlated with each other. Hypothesis of increasing values of film layer will increased the resistance value of a material and sample were determined at room temperature. Figure 8 shows the resistivity measurement of SPS/SPNCC films with 0.10 wt \% SPNCCs concentration with applied different number of film layers.

Figure 8 shows that the resistivity value increased for more layers of SPS/SPNCC films. This means that the fiber inhibits the current exponentionally with the increasing number of applied SPS/SPNCC layers. The differences between fiber loading of SPNCCs according to this analytical technique and the electrical resistivity readings are reported in Fig. 8. It is shown that three layers of SPS/SPNCC films carry more electrical resistivity compared others. This hypothesis can be applied to other layers of film since the lowest amount of resistiv-

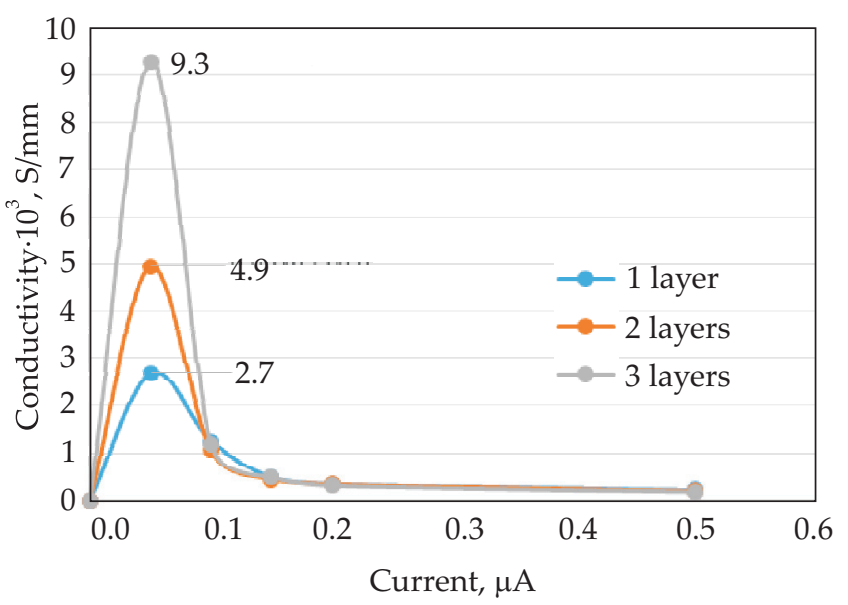

Fig. 9. Conductivity of materials with a different number of SPC/SPNCC film layers

ity for a current value of $0.5 \mu \mathrm{A}$ was for a single layer of SPS/SPNCC, which had a value of $4.8 \cdot 10^{3}(\Omega \cdot \mathrm{mm})$.

\section{Effect of SPS/SPNCCs film layers on conductivity}

Electrical conductivity is the degree to which specific material conducts electricity and it is also a fundamental property of materials that quantifies how strongly it resist or conduct electric current. Electrical conductivity is measured in Siemen's per meter $(\mathrm{S} / \mathrm{m})$ and it is the reciprocal of the electrical resistivity of the materials on low applied current. The conductivity is calculated from the experimental result of resistance and resistivity from previous data collected using the four-probe measurement device. Figure 9 shows the conductivity of the films with concentration $0.10 \mathrm{wt} \%$ of SPNCCs.

In Fig. 9, it is observed that the conductivity value decreases following an increase in the resistivity value.

$\mathrm{T}$ a b l e 4. Comparison of resistivities in different natural/synthetic fiber composites

\begin{tabular}{|c|c|c|c|c|}
\hline Authors & Measurement & \multicolumn{2}{|c|}{ Composite materials } & Electrical resistivity \\
\hline Orlova [40] & Four-probe method & Silicon & Silicon carbide & $3 \cdot 10^{-3}$ to $20 \cdot 10^{-3}$ \\
\hline Naik and Mishra [1] & Concentric ring probe & Banana & HDPE & $3.8 \cdot 10^{13}$ to $4.5 \cdot 10^{13}$ \\
\hline Naik and Mishra [1] & Concentric ring probe & Hemp & HDPE & $3.2 \cdot 10^{13}$ to $3.8 \cdot 10^{13}$ \\
\hline Naik and Mishra [1] & Concentric ring probe & Agave & HDPE & $3.3 \cdot 10^{13}$ to $3.9 \cdot 10^{13}$ \\
\hline Bhardwaj [5] & Four-probe method & Rice Husk & Epoxy & $90.9 \cdot 10^{4}$ \\
\hline Malik et al. [3] & Four-probe method & Silicon Carbide & Boron Nitride & $3.7 \cdot 10^{-2}$ to $8.1 \cdot 10^{-3}$ \\
\hline Lukianova et al. [41] & Four-probe method & Silicon Nitride & $\mathrm{Y}_{2} \mathrm{O}_{3}-\mathrm{Al}_{2} \mathrm{O}_{3}$ & $3.16 \cdot 10^{9}$ to $1.73 \cdot 10^{11}$ \\
\hline Lukianova et al. [41] & Four-probe method & Silicon Nitride & $\mathrm{MgO}-\mathrm{Al}_{2} \mathrm{O}_{3}$ & $3.87 \cdot 10^{10}$ \\
\hline Soltys et al. [42] & Impedance analyzers & Glass & Alkali halide & $1.09 \cdot 10^{11}$ to $2.93 \cdot 10^{11}$ \\
\hline Soltys et al. [42] & Impedance analyzers & Glass & Sodium borate & $4.55 \cdot 10^{2}$ to $6.37 \cdot 10^{4}$ \\
\hline Soltys et al. [42] & Impedance analyzers & Glass & Vanadate & $4.61 \cdot 10^{3}$ to $2.13 \cdot 10^{4}$ \\
\hline Devi et al. [43] & Two-probe electrode & Natural rubber & Polypyrrole & 16 to $1.21 \cdot 10^{3}$ \\
\hline Current study & Four-probe method & SPS & SPNCCs & $3.14 \cdot 10^{2}$ to $1.47 \cdot 10^{4}$ \\
\hline
\end{tabular}


The conductivity was determined with the supplied current ranging from $0.00-0.50 \mu \mathrm{A}$. It was shown that when the current is increased to $0.10 \mu \mathrm{A}$, a peak in the conductivity of SPS/SPNCC films is displayed. It is also shown that the maximum value of conductivity occurs at three layer films with the value of $92.87 \cdot 10^{-4} \mathrm{~S} / \mathrm{mm}$. It is also noted that a single layer of SPS/SPNCCs had the least electrical conductivity value, i.e. $0.00 \mu \mathrm{A}$ to $0.10 \mu \mathrm{A}$ is $2.68 \cdot 10^{-3} \mathrm{~S} / \mathrm{mm}$. An increasing trend was observed from $0.00 \mu \mathrm{A}$ to $0.10 \mu \mathrm{A}$ and a cutoff point is determined for SPS/SPNCCs film at $0.10 \mu \mathrm{A}$ and eventually the conductivity value decreased uniformly. These traits occurred until the amount of current was $0.50 \mu \mathrm{A}$, which brings the meaning of limitations of current flow and conductivity parameter for every layer.

\section{Electrical properties of SPC/SPCC films and other polymer composites}

Table 4 shows a comparison of the resistivity values in polymer composites. From Table 4 , silicon carbide/ boron nitride had the lowest resistivity value from $\left[3 \cdot 10^{-3}\right.$ to $\left.20 \cdot 10^{-3}(\Omega \cdot \mathrm{cm})\right]$, indicating that the current can flow through it and act fully as a conductor [3]. According to Orlova [40], the resistivity value of composites was dependent on the residual porosity derived from natural wood (eucalyptus, beech, sapele) and the Si content. SPS/SPNCC films with different concentrations of SPNCCs carries the highest resistance values $\left[3.14 \cdot 10^{2}\right.$ to $\left.1.47 \cdot 10^{4}(\Omega \cdot \mathrm{cm})\right]$ compared to layered films from untreated banana fiber, which showed the highest surface resistivity $\left[3.8 \cdot 10^{13}\right.$ to $\left.4.5 \cdot 10^{13}(\Omega \cdot \mathrm{cm})\right]$. SPS/SPNCC films are insulating materials that can be used for human protection against electrostatic and electric shock where the minimum and maximum allowable current flow through is $0.11 \mathrm{~mA}$ to $5 \mathrm{~mA}$.

\section{CONCLUSIONS}

The resistance and resistivity of SPS/SPNCC film values increase at higher SPNCC concentrations and current input applied to the film. With SPS film, the resistivity increased from $3.78 \cdot 10^{3}(\Omega \cdot \mathrm{mm})$ at $0.02 \mu \mathrm{A}$ to $13.19 \cdot 10^{3}(\Omega \cdot \mathrm{mm})$ at $0.20 \mu \mathrm{A}$. This compared to SPS/SPNCC concentrations of SPNCCs at $1.0 \mathrm{wt} \%$ that have lower resistivity of $2.7 \cdot 10^{3}(\Omega \cdot \mathrm{mm})$ at $0.02 \mu \mathrm{A}$ and higher compared to SPS film, $14.68 \cdot 10^{3}(\Omega \cdot \mathrm{mm})$ at $0.20 \mu \mathrm{A}$. For the layered effect of electrical resistivity of various concentration of SPS/SPNCC films at room temperature, it can be summarized that for the single layer of SPS/SPNCC films, the resistivity increased from $0.37 \cdot 10^{3}(\Omega \cdot \mathrm{mm})$ at $0.05 \mu \mathrm{A}$ to $4.8 \cdot 10^{3}(\Omega \cdot \mathrm{mm})$ at $0.50 \mu \mathrm{A}$. This can be compared to SPS/SPNCC concentrations of SPNCCs at $1.0 \mathrm{wt} \%$ for 3 layer film that have a lower resistivity of $0.11 \cdot 10^{3}(\Omega \cdot \mathrm{mm})$ at $0.05 \mu \mathrm{A}$ and increase resistivity value to $5.95 \cdot 10^{3}(\Omega \cdot \mathrm{mm})$ at $0.50 \mu \mathrm{A}$. There are also no changes to the physical appearance of the film due to the small amounts of current were tested. The resistivity increase uniformly by increasing the current supply thus this hypothesis applies to conductivity, which will decrease in value with the increase in the current being supplied.

\section{ACKNOWLEDGMENTS}

The authors are indebted to Md Damiri bin Md Sairi and Maimon binti Zainal Abiddin for their tremendous support in completing this project. The project was funded by HICoE grant from Ministry of Education Malaysia vote number 6369107.

\section{REFERENCES}

[1] Naik J.B., Mishra S.: Polymer-Plastics Technology and Engineering 2005, 44, 687. http://dx.doi.org/10.1081/PTE-200057818

[2] Hazrol M.D., Sapuan S.M., Zuhri M.Y.M., Ilyas R.A.: "Electrical properties of sugar palm nanocellulose fiber reinforced sugar palm starch biopolymer composite", Prosiding Seminar Enau Kebangsaan 2019, Bahau, Negeri Sembilan, Malaysia: Institute of Tropical Forest and Forest Products (INTROP), Universiti Putra Malaysia 2019, pp. 57-62.

[3] Malik R., Kim H., Kim Y., Kim K.J.: Ceramics International 2018, 44, 16394.

http://dx.doi.org/10.1016/j.ceramint.2018.06.049

[4] Xie G., Ding D., Zhang G.: Advances in Physics: X 2018, 3,719 . http://dx.doi.org/10.1080/23746149.2018.1480417

[5] Bhardwaj G.: "Measurment of electrical conductivity of natural fiber composite" MTech Thesis, National Institute of Technology, Rourkela 2013.

[6] Jumaidin R., Ilyas R.A., Saiful M. et al.: Journal of Advanced Research in Fluid Mechanics and Thermal Sciences 2019, 61, 273.

[7] Jumaidin R., Saidi Z.A.S., Ilyas R.A. et al.: Journal of Advanced Research in Fluid Mechanics and Thermal Sciences 2019, 62, 43.

[8] Saifulazry S., Al O., Tahir P. et al.: International Journal of Recent Technology and Engineering 2019, 8, 528. http://dx.doi.org/10.35940/ijrte.B1104.0782S419

[9] Maisara A.M.N., Ilyas R.A., Sapuan S.M. et al.: International Journal of Recent Technology and Engineering 2019, 8, 510.

http://dx.doi.org/10.35940/ijrte.b1100.0782s419

[10] Ilyas R.A., Sapuan S.M., Ibrahim R. et al.: Journal of Biobased Materials and Bioenergy 2020, 14, 1. http://dx.doi.org/10.1166/jbmb.2020.1951

[11] Atikah M.S.N., Ilyas R.A., Sapuan S.M. et al.: Polimery 2019, 64, 27.

http://dx.doi.org/10.14314/polimery.2019.10.5

[12] Norizan M.N., Abdan K., Ilyas R.A.: Polimery 2020, 65,34 . http://dx.doi.org/10.14314/polimery.2020.2.5

[13] Nurazzi N.M., Khalina A., Sapuan S.M., Ilyas R.A.: Polimery 2019, 64, 12. http://dx.doi.org/10.14314/polimery.2019.10.3 
[14] Atiqah A., Jawaid M., Sapuan S.M. et al.: Journal of Materials Research and Technology 2019, 8, 3726. http://dx.doi.org/10.1016/j.jmrt.2019.06.032

[15] Sanyang M.L., Ilyas R.A., Sapuan S.M., Jumaidin R.: "Bionanocomposites for Packaging Applications" (Eds. Jawaid M., Swain S.K.), Cham: Springer International Publishing, 2018, pp. 125-147. http://dx.doi.org/10.1007/978-3-319-67319-6_7

[16] Ilyas R.A., Sapuan S.M., Ibrahim R. et al.: Journal of Materials Research and Technology 2019, 8, 4819. http://dx.doi.org/10.1016/j.jmrt.2019.08.028

[17] Ilyas R.A., Sapuan S.M., Ishak M.R., Zainudin E.S.: International Journal of Biological Macromolecules 2019, 123, 379. http://dx.doi.org/10.1016/j.ijbiomac.2018.11.124

[18] Ilyas R.A., Sapuan S.M., Ishak M.R., Zainudin E.S.: BioResources 2017, 12, 8734. http://dx.doi.org/10.15376/biores.12.4.8734-8754

[19] Ilyas R.A., Sapuan S.M., Ishak M.R., Zainudin E.S.: Carbohydrate Polymers 2018, 202, 186. http://dx.doi.org/10.1016/j.carbpol.2018.09.002

[20] Ilyas R.A., Sapuan S.M., Ibrahim R. et al.: Journal of Materials Research and Technology 2019, 8, 2753. http://dx.doi.org/10.1016/j.jmrt.2019.04.011

[21] Sahari J., Sapuan S.M., Zainudin E.S., Maleque M.A.: Journal of Biobased Materials and Bioenergy 2013, 7, 90. http://dx.doi.org/10.1166/jbmb.2013.1267

[22] Radzi A.M., Sapuan S.M., Jawaid M., Mansor M.R.: BioResources 2018, 13, 6238.

[23] Sapuan S.M., Ilyas R.A.: INTROPica 2017, pp. 5-7.

[24] Sapuan S.M., Ishak M.R., Leman Z. et al.: INTROPica 2017, pp. 12-13.

[25] Ilyas R.A., Sapuan S.M., Sanyang M.L. et al.: Current Analytical Chemistry 2018, 14, 203. http://dx.doi.org/10.2174/1573411013666171003155624

[26] Ilyas R.A., Sapuan S.M., Ishak M.R. et al.: "Sugar Palm Biofibers, Biopolymers, and Biocomposites" First Edition, Boca Raton, FL : CRC Press/Taylor \& Francis Group, CRC Press 2018, pp. 189-219. http://dx.doi.org/10.1201/9780429443923-10

[27] Mazani N., Sapuan S.M., Sanyang M.L. et al.: "Lignocellulose for Future Bioeconomy", Elsevier, 2019, pp. 315-332. http://dx.doi.org/10.1016/B978-0-12-816354-2.00017-7

[28] Abral H., Basri A., Muhammad F. et al.: Food Hydrocolloids 2019, 93, 276.

http://dx.doi.org/10.1016/j.foodhyd.2019.02.012
[29] Abral H., Ariksa J., Mahardika M. et al.: Food Hydrocolloids 2020, 98, 105266. http://dx.doi.org/10.1016/j.foodhyd.2019.105266

[30] Abral H., Ariksa J., Mahardika M. et al.: Polymer Testing 2019, 106186.

http://dx.doi.org/10.1016/j.polymertesting.2019.106186

[31] Ilyas R.A., Sapuan S.M., Ishak M.R., Zainudin E.S.: IOP Conference Series: Materials Science and Engineering 2018, 368, 12006. http://dx.doi.org/10.1088/1757-899X/368/1/012006

[32] Ilyas R.A, Sapuan S.M., Ishak M.R., Zainudin E.S.: Journal of Advanced Research in Fluid Mechanics and Thermal Sciences 2018, 51, 234.

[33] Ilyas R.A., Sapuan S.M., Atiqah A. et al.: Polymer Composites 2019, 1-9. http://dx.doi.org/10.1002/pc.25379

[34] Tsanov T., Mokreva P., Terlemezyan L.: Polymers and Polymer Composites 1997, 5, 299.

[35] Whetzel J.: "Why Is Conductivity Important?", SciencingCom 2017.

[36] Sanyang M.L., Sapuan S.M., Jawaid M. et al.: BioResources 2016, 11, 4134. http://dx.doi.org/10.15376/biores.11.2.4134-4145

[37] Ilyas R.A., Sapuan S.M., Ishak M.R.: Carbohydrate Polymers 2018, 181, 1038. http://dx.doi.org/10.1016/j.carbpol.2017.11.045

[38] Halimatul M.J., Sapuan S.M., Jawaid M. et al.: Polimery 2019, 64, 27. http://dx.doi.org/10.14314/polimery.2019.9.4

[39] Halimatul M.J., Sapuan S.M., Jawaid M. et al.: Polimery 2019, 64, 32. http://dx.doi.org/10.14314/polimery.2019.6.5

[40] Orlova T.S., Popov V.V., Quispe Cancapa J. et al.: Journal of the European Ceramic Society 2011, 31, 1317. http://dx.doi.org/10.1016/j.jeurceramsoc.2010.06.015

[41] Lukianova O.A., Khmara A.N., Perevislov S.N. et al.: Ceramics International 2018. http://dx.doi.org/10.1016/j.ceramint.2018.09.198

[42] Sołtys M., Górny A., Pisarska J., Pisarski W.A.: Journal of Non-Crystalline Solids 2018, 498, 352. http://dx.doi.org/10.1016/j.jnoncrysol.2018.03.033

[43] Devi D.S.P., Bipinbal P.K., Jabin T., Kutty S.K.N.: Journal of Materials \& Design 2013, 43, 337. http://dx.doi.org/10.1016/j.matdes.2012.06.042

Received 30 X 2019. Revised version 3 I 2020. 